NBER WORKING PAPER SERIES

\title{
WERE COMPULSORY ATTENDANCE AND CHILD LABOR LAWS EFFECTIVE? AN ANALYSIS FROM 1915 TO 1939
}

\author{
Adriana Lleras-Muney \\ Working Paper 8563 \\ http://www.nber.org/papers/w8563 \\ NATIONAL BUREAU OF ECONOMIC RESEARCH \\ 1050 Massachusetts Avenue \\ Cambridge, MA 02138 \\ October 2001
}

I am very grateful to Ana Corbacho, Rajeev Dehejia, Lena Edlund, Randall Kroszner, Ken Leonard, Rohini Pande, Alexander Peterhansl and an anonymous referee for their comments and suggestions. I am especially grateful to my advisor Sherry Glied who fully supported me throughout this project. This research was partially funded by Columbia University' Public Policy Consortium and the Bradley Foundation. The views expressed herein are those of the author and not necessarily those of the National Bureau of Economic Research.

(C) 2001 by Adriana Lleras-Muney. All rights reserved. Short sections of text, not to exceed two paragraphs, may be quoted without explicit permission provided that full credit, including (C) notice, is given to the source. 
Were Compulsory Attendance and Child Labor Laws Effective?

An Analysis from 1915 to 1939

Adriana Lleras-Muney

NBER Working Paper No. 8563

October 2001

JEL No. I2, N3, N4

\begin{abstract}
Secondary schooling experienced incredible growth in the first 40 years of the $20^{\text {th }}$ Century. Was legislation on compulsory attendance and child labor responsible for this growth? Using individual data from the 1960 census, I estimate the effect of several laws on educational attainment for individuals who were 14 years old between 1915 and 1939. The results show that legally requiring a child to attend school for one more year, either by increasing the age required to obtain a work permit or by lowering the entrance age, increased educational attainment by about $5 \%$. The effect was similar for white males and females, but there was no effect for blacks. Continuation school laws, which required working children to attend school on a part time basis, were effective for white males only. These laws increased the education only of those in the lower percentiles of the distribution of education. By increasing the education of the lower tail, the laws contributed to the decrease in educational inequality, perhaps by as much as $15 \%$. States with more wealth and a higher percentage of immigrants were more likely to pass more stringent laws, and states with higher percentage of blacks were less likely to do so. Importantly, the results suggest that the laws were not endogenous during this period.
\end{abstract}

\author{
Adriana Lleras-Muney \\ Department of Economics \\ Princeton University \\ Princeton, NJ 08544 \\ and NBER \\ alleras@princeton.edu
}


In the first half of the $20^{\text {th }}$ century, secondary schooling in the U.S. experienced incredible growth: the percentage of young adults with high school degrees increased by a factor of five from 1910 to 1940 (Goldin and Katz, 1997). Many factors help explain this unprecedented increase in educational attainment. The demand for educated workers had increased as a result of the increase of white collars jobs (Goldin and Katz, 1998). The demand for young labor had fallen as immigrants came to the U.S.. And agricultural wages had decreased because of technological changes in agriculture (Osterman, 1980). This resulted in lowered labor demand in the agricultural sector, which employed a significant number of young workers. ${ }^{1}$ Some states also wanted to increase education for other reasons, often correlated with state income and state homogeneity (Goldin and Katz, 1997). During this period, there was also an enormous amount of legislation geared toward increasing school attendance and curbing child labor. ${ }^{2}$ The purpose of this paper is to answer the question of whether state compulsory attendance and child labor laws contributed to the increase in educational attainment from 1914 to 1939.

With one exception (Schmidt, 1996), no one has analyzed the impact of these laws during this period ${ }^{3}$ - the most important years in the expansion of secondary education, when compulsory attendance laws are most likely to have affected many people. This paper contributes to the literature by analyzing a detailed set of laws, examining their effect on the entire distribution of education, analyzing the factors that led to legislative changes in the laws during this period, and testing for the endogeneity of the laws.

\footnotetext{
${ }^{1}$ In $1910,72 \%$ of children $10-15$ years of age engaged in gainful occupations were employed in agriculture (Bureau of the Census, 1924).

${ }^{2}$ The number of changes for 1915-1939 will be analyzed in the next section.

${ }^{3}$ Acemoglu and Angrist (1999) and Lang and Kropp (1986) included this period in their data, but they analyze the impact of the laws over a much larger span of time.
} 
The results (using individual census data from 1960) show that laws requiring a child to attend school for one more year increased educational attainment by about 18 days, ${ }^{4}$ and decreased educational inequality. Importantly, the results also suggest that the laws were not endogenous during this period, in the sense that compulsory attendance and child labor laws appear to have caused education to increase, not vice-versa. ${ }^{5}$

This paper is organized as follows. Section 1 contains a short description of the history of compulsory attendance and child labor laws, and it reviews previous studies in this area and describes the strategy pursued in this study. Section 2 describes the data. The econometric strategy and the results using individual-level results are in Section 3. Section 4 looks at the factors that explain the passage of the laws. Section 5 analyzes the effects on the distribution of education. The endogeneity tests are presented in Section 6 and Section 7 concludes.

\section{What do we know about compulsory attendance and child labor laws?}

Compulsory attendance laws were first enacted by Massachusetts in $1852 .^{6}$ By 1918 all states had such laws. From their early inception (and to this day) the laws were complex. ${ }^{7}$ They varied greatly across states in their specifications and enforcement.

Compulsory attendance laws specified a minimum and a maximum age between which attendance was required, and the minimum period of attendance. They also provided penalties and procedures for non-compliance and listed the conditions under which individuals could be exempted from attending school. Exemptions were given for a variety of

\footnotetext{
${ }^{4}$ Although they might not have decreased employment. For example see Moehling (1999), Goldin (1979).

${ }^{5}$ Endogeneity here refers to econometric endogeneity. The argument is that the laws did not result from increases in education or any other variable that explains both.

${ }^{6}$ Earlier legislation on compulsory education existed in many states (the first compulsory education law was enacted by Massachusetts in 1642 -- see Katz or Kotin et al.). Compulsory attendance laws forced parent to send their children to school, not just to provide them with an education.

${ }^{7}$ See Kotin and Aikman (1980).
} 
reasons, including achievement of a certain level of education (e.g. the completion of eighth grade), mental or physical disability, distance from school, poverty, and lack of schools.

The most important exemption was that, under certain conditions, children were allowed to get work permits and leave school at an early age, generally lower than the dropout age specified by compulsory attendance laws. Child labor laws, which extensively regulated the employment of minors, were in place in all states by $1914 .^{8}$

Child labor laws and compulsory attendance laws were often not "coordinated" in the sense that each specified different requirements for leaving school. For example, in 1924 in Pennsylvania the ages for compulsory attendance were 8 to 16 , but a child could be excused after completing the $8^{\text {th }}$ grade. Child labor laws in that state however allowed 14 year-olds with 6 years of education to get work permits. Continuation school laws, which forced children at work to continue their education on a part-time basis, were the only laws that attempted to bridge the gap between labor and attendance laws.

There is little agreement regarding the effectiveness of these laws. Stigler (1950) first noted that although enrollments were higher in states with higher minimum compulsory ages in 1940, the relationship broke down when he classified states by per capita income and racial composition. Landes and Solomon (1972) analyze the impact of the laws on attendance from 1880 to 1910 . They find that compulsory education laws did not contribute to the increase in enrollments during this period. They further suggest that states with higher enrollments were more likely to pass more restrictive laws than other states. Eisenberg (1988) shows that attendance levels and expenditures per school-aged child were important factors in explaining the passage of the compulsory attendance laws from 1870 to 1915 .

\footnotetext{
${ }^{8}$ These laws also included several conditions for the granting of the permits, such as educational requirements, and exceptions under which those not meeting the general requirements could obtain permits.
} 
But none of these papers focuses on the 1914-1939 period, when the laws are most likely to have affected many. Also, research in other social sciences has found that during the preceding period (up to 1915) the laws were ineffective, ${ }^{9}$ but that the relevant laws were enforced by the 1920s. ${ }^{10}$ Stigler (1950) and Edwards (1978) do look at the impact of the laws on enrollments from 1940 to 1960 and conclude that they were not effective, but there is little time-variation in the laws after the war, whereas there were many legislative changes from 1914 to 1939 (see next section).

There are a number of studies that find that the laws were effective. Schmidt (1996) finds large effects of compulsory education laws on the probability of high school completion between 1920 and 1934. Lang and Kropp (1986), using data from 1908 to 1970, show that compulsory education laws affect enrollments, even for groups not targeted by the laws. Acemoglu and Angrist (2000) find that the effects of the laws on educational attainment are positive and significant, the effects of child labor laws being larger. The two latter studies, although covering many decades, do not control for time- and state-specific variables, so their results could be biased.

Two studies, Margo and Finegan (1996) and Angrist and Krueger (1991), use a significantly different methodology to assess the impact of the laws: since the laws specified the age at which children could leave school, those children born earlier in the year would obtain fewer years of schooling. Using this natural experiment, Angrist and Krueger (1991)

\footnotetext{
${ }^{9}$ The United States Commissioner of Education said in 1886 that "in many instances (...) the compulsory education law, if not actually dead letter, is practically so." Many state laws did not provide enforcement mechanisms, and if they did, they often lacked enforcement means. See Katz (1976) and Ensign (1921).

${ }^{10}$ Historians and lawyers believe that compulsory attendance laws were enforced by 1920 . Most states instituted school censuses to count the school population and assess the needs of each district. Truant officers ensured that children were in school and fined parents in case of non-compliance. Also, expenditures in education increased (See Tyack, 1974 and Katz, 1976). Note however the laws might not have been enforced in all states: Margo (1986) reports that in Alabama expenditures on enforcement were low and that "teachers cited non-enforcement of attendance laws as a major weakness in Alabama schools".
} 
compare attendance rates by state, cohort and quarter of birth between 1960 and 1980; Margo and Finegan (1996) make similar analyses using the more detailed information on month of birth available in the 1900 census. Both studies find that the laws were effective, but there has been controversy about whether quarter (month) of birth affects education only because of compulsory schooling laws. ${ }^{11}$

This paper provides new evidence on these laws. In particular I make use of the fact that the laws were complex and were likely to work in combination with one another. I analyze the factors that resulted in changes in compulsory schooling and child labor legislation, and include a very rich set of controls for state characteristics that potentially affected both education and the passage of these laws for this period. More importantly, I look at the effect of the laws on the entire distribution of education, not only at the effect on average education or enrollments. If these laws were effective they would affect only those at the lower end of the distribution of education, thereby lowering education inequality. And I explore the issue of whether the laws increased educational attainment rather than resulting from high education levels. These results therefore support the use of compulsory schooling and child labor laws as instruments for education. ${ }^{12}$ Note that I concentrate on the effect of the laws on completed years of education rather than on attendance or enrollments because education is the more important social outcome.

\section{Data Description and Sources}

The data on compulsory attendance and child labor laws were collected from multiple sources. Eight years of state-level data (1915, 1918, 1921, 1924, 1928, 1930, 1935 and 1939) on these laws were collected. Some additional information was available for other years. I

\footnotetext{
${ }^{11}$ See Bound and Jaeger (1996).

${ }^{12}$ For papers that use these laws as instruments see Acemolgu and Angrist (2000) and Lleras-Muney (2001).
} 
imputed missing observations by using the older values. The information was not consistently recorded by a single agency. In case of conflicting pieces of data, the later information was used to correct the data. ${ }^{13}$ The data contain information on the maximum age by which a child must enter school (entrance age), the minimum age at which he can dropout of school (dropout age), the minimum level of education required to be exempted from school (education to dropout), the minimum age required to obtain a work permit and leave school (work permit age), the minimum education level required to obtain a work permit (education to work), and information on whether working children were required to go to school on a part time basis (continuation school).

Following Acemoglu and Angrist (2000), I constructed two additional variables. The first one, childlaw is defined as work permit age minus entrance age. Childlaw is a measure of the number of years a person would have to attend school if he entered school at the age that compulsory attendance laws required and left as soon as he reached the age necessary to obtain a labor permit. For example, in a given state in 1935, an individual must start school at age 7 and may get a work permit at 15; childlaw would be equal to 8 years in this case. If there was no law, the value for childlaw is set to 0 . The second variable, comlaw is defined as the number of years a person was forced to go to school if both the entrance and the dropout age specified by compulsory attendance laws were enforced (i.e. leaving age minus entrance age).

National trends for these laws can be assessed by looking at graphs in Table 1. These trends reflect a relatively large number of overall changes in legislation: 20 states changed their continuation schools laws at least once, 25 states changed the entrance age at least once,

\footnotetext{
$\overline{{ }^{13} \text { See Appendix A for more details. }}$
} 
30 changed leaving age at least once, 29 changed work permit age at least once. The same is true for the other aspects of the laws.

Overall, the laws tended to require more attendance over time, although it was not always the case that states passed laws that required more years of education. ${ }^{14}$ Also the timing of the increases was different for each law. ${ }^{15}$ The education required to obtain a labor permit and the education required to be exempted from school increased overtime, but they both fell short of matching the implicit number of years of schooling required by compulsory attendance and/or child labor laws.

These trends for national averages conceal a great deal of cross-sectional variation in any given year however. To illustrate this other type of variation I present tabulations of the laws in three different years $(1915,1928$ and 1939) in Table 2.

These data on compulsory education are matched to census data, from the Integrated Public Use Microdata Series (IPUMS) 1960 census 1\% sample. ${ }^{16}$ The Census provides information on sex, race, state-of-residence, state-of-birth, age and whether parents are foreign born. I kept all individuals that were 14 years of age in the 48 states between 1914 and 1939 (i.e. those born between 1901 and 1925 in the U.S.), except for those with missing values on their education variable (highest grade completed). Occasionally I also use the

\footnotetext{
${ }^{14}$ For example, Louisiana changed the age at which a child could leave school from 16 in 1915, down to 14 in 1916, back up to 16 in 1921, back down to 14 in 1923, back up again to 15 in 1930, and down again to 14 in 1935 !

${ }^{15}$ The average age at which a child must enter school decreased constantly throughout the period. Laws related to continuation school were mostly implemented in the early 20 s and remained mostly unchanged thereafter. Changes related to the education required for a labor permit were implemented in the late 20 s, but the education necessary to be exempted from school increased also in the late $30 \mathrm{~s}$. The age required for a labor permit changed significantly both in the early 20 s and late 30 s.

${ }^{16}$ The data comes from the IPUMS 1960 general sample and was downloaded from the web site http://www.ipums.umn.edu
} 
1950 census, which however contains fewer observations and was therefore not used for the main results. ${ }^{17}$

I matched each individual to the laws that were in place in their state-of-birth ${ }^{18}$ when they were 14 years old. I chose this age because that is the lowest common denominator for minimum leaving ages across states. ${ }^{19}$ Schmidt (1996) tested this assumption and found the effect of the laws was largest when looking at age 14 .

Finally, I also match individuals with characteristics of their state-of-birth when they were 14. The state-level data include state expenditures on education, number of schoolbuildings per acre, percent of the population that was living in urban areas, percent of the white population that was foreign born, percent of the population that was black, percent of the population employed in manufacturing, average annual wages in manufacturing per worker, average value of farm property per acre, and number of doctors per capita. Again, these data were collected from multiple sources and imputed for the years in which there were missing values. ${ }^{20}$ The summary statistics for the data are presented in Appendix C.

\section{Econometric Model and Results}

For each individual I estimate the following equation:

$$
\mathrm{ED}_{\mathrm{ics}}=\beta \mathrm{X}_{\mathrm{ics}}+\delta \mathrm{CL}_{\mathrm{cs}}+\mu \mathrm{Z}_{\mathrm{cs}}+\alpha_{\mathrm{c}}+\gamma_{\mathrm{s}}+\mathrm{R}_{\mathrm{rc}}+\varepsilon_{\mathrm{ics}}
$$

\footnotetext{
${ }^{17}$ The 1920 and 1940 censuses were not used for several reasons. The 1920 census is not very appealing because I can only look at a few cohorts (those that were 14 between 1915 and 1920). Also note that the outcome variable that I use is completed years of education. This variable would be censored for most individuals in the 1920 census and for many individuals in 1940 as well. Additionally, in 1940 there are very few sample lines for the analysis.

${ }^{18}$ This matching procedure assumes that individuals went to school in the state where they were born. Inevitably some individuals were mismatched. However Card and Krueger (1992) showed that mobility during the first half of the $20^{\text {th }}$ century was low and that the error that this procedure generates is small, around $10 \%$. Furthermore, if such an error exists, it likely will be uncorrelated with laws on compulsory attendance and with child labor laws, because these laws were probably not the reason why individuals moved across states. Indeed if I regress mobility between state-of-birth and state-of-residence in 1960 as a function of education, compulsory education laws, and all other covariates used in this paper, I find that the laws are not significant. The F-statistic of joint significance of the laws has a value of 1.17 ( $p$ value of 0.3151 ).

${ }^{19}$ With the exception of North Carolina (1915-1917) and Virginia (1915-1922).
} 
where ED is the number of years of education for individual i, of cohort $\mathrm{c}$, born in state $\mathrm{s}$, in region $\mathrm{r}$; $\mathrm{X}_{\mathrm{ics}}$ is a vector of individual characteristics, such as sex and race; $\mathrm{CL}$ is a vector of compulsory education and child labor laws in state $\mathrm{s}$ for cohort $\mathrm{c} ; \mathrm{Z}_{\mathrm{cs}}$ are state of birth characteristics at age $14 ; \alpha_{c}$ are cohort effects; $\gamma_{\mathrm{s}}$ are state effects; $\mathrm{R}_{\mathrm{rc}}$ are region- and cohortspecific effects; and $\varepsilon_{\text {ics }}$ is the error term. The errors are clustered at the state-of-birth and cohort level, and they are corrected for heteroskedasticity using White's estimator. All the regressions reported here include state and cohort effects. Thus, the effect of the laws is identified from variations in the laws within states over time.

The results are presented in table 3. In regression 1, I include childlaw, and a dummy variable equal to one if the state had a continuation school law. The coefficient on childlaw is about 5 percentage points. Thus an increase in childlaw of one raises educational attainment by about 18 days. The coefficient on continuation school is also about $5 \%$, but it is insignificant. The F-statistics on the joint significance of these two variables is highly significant.

Regression 2 adds a variable that contains the level of education necessary to obtain a work permit (education to work). This variable turns out to be insignificant. Its addition does not change the coefficients of the other laws, and it lowers the value of the F-statistic of the joint significance of the laws. In regression 3, I decompose childlaw into its two components: the age at which a child had to enter school (entrance age) and the age at which he could get a work permit and leave school (work permit age). The coefficients of both variables are significant at the $5 \%$ level. I test whether the coefficient on entry age is the same in absolute value as that of work age. The test does not reject the null at a $5 \%$ level. ${ }^{21}$ This result has an

\footnotetext{
${ }^{20}$ See Appendix B for more details.

${ }^{21}$ The test for equality is still not rejected if education requirements are not included.
} 
interesting public policy implication. Historically it was difficult to pass legislation to increase the work permit age. ${ }^{22}$ The result implies that it is possible to increase educational attainment by lowering the entrance age, which might be more politically feasible and easier to implement than increasing the work permit age (although the payoff, in terms of human capital, might be different).

Regressions 4 through 6 repeat all the estimations above but use the age at which an individual was allowed to drop out of school according to the compulsory attendance laws (dropout age) rather than the age at which he could get a work permit. Also I replace the education required for a work permit with the education required to dropout from school according to compulsory attendance laws. None of the variables are significant, except for the age at which an individual must enter school.

Table 4 contains a number of specification checks. Column 1 shows the results only for states where the number of compulsory years of schooling is positive. The coefficient is still significant (in fact increases) suggesting that it was the changes in existing laws rather than introduction of new laws that were responsible for the increases in education. Columns 2 and 3 address the issue of measurement error in the laws. Column 2 shows the results restricting the sample to the 8 cohorts for which no imputation in the laws has been done. The results from restricting the sample to those that are still living in their state-of-birth in 1960 are in Column 3. In both cases the coefficient of childlaw is statistically identical to that in Table 2, suggesting these sources of error are not very important. Finally in column 4, I reestimate the model using the 1950 census. The results using the 1960 census cross section are

\footnotetext{
${ }^{22}$ Between 1914 and 1938 the movement to make child labor law federal encountered opposition from the southern states and from the Supreme Court which found the federal child labor bills of 1916 and 1918 unconstitutional. It was not until 1938 that child labor laws were made federal, in spite of the opposition of manufacturer, farmers and textile interests. (Kotin and Aikman). One of the main features of the federal law is
} 
derived from synthetic cohort variation, rather than real cohort variation. This can be problematic if for example individuals die non-randomly. The results however, suggest that that the synthetic cohort approach is not generating any bias.

In all cases the estimate of the effect of the laws (5\%) is similar to those reported by other researchers. Acemoglu and Angrist (2000) report an increase of between 1 and 6 percentage points. Angrist and Krueger (1991) find that the impact of the laws was about 4\% in 1960. Eisenberg (1988) finds an effect of about $2 \%$.

Finally I analyze the effects of the laws by race and gender. There is reason to believe that these education policies might have affected groups in different ways. For example, researchers have suggested that the quality of education during the $20^{\text {th }}$ century was very different for blacks. ${ }^{23}$ If the laws had a differential impact, they might help explain the evolution of gender and race gaps. The results are presented in Table 5. As in Margo (1990), I find that the laws had no impact on blacks. ${ }^{24}$ It is unclear why this is the case. It is possible that blacks faced much lower returns to education, ${ }^{25}$ so that even when confronted with penalties it was still better to work than to attend school. It is also possible that law enforcement did not concern itself with this group; i.e. that these laws were never meant to affect blacks. Most probably however, blacks were very likely to be exempted by law due to the lack of schools and school resources (also because blacks were more likely to be poor).

\footnotetext{
that it made the work permit age 16 , rather than 14 , which was the most common value across states during the period.

${ }^{23}$ See Card and Krueger (February 1992), Margo (1990).

${ }^{24}$ This result calls into question previous findings in the literature that argue that quarter of birth can predict education only because of its interaction with compulsory schooling laws. Those papers find that quarter of birth affected educational attainment for blacks, but the results here suggest the laws did not affect them (although note that Margo (1990) does find effects of the laws for blacks, but these become insignificant when state dummies are included).

${ }^{25}$ Welch (1973) presents evidence that the returns to education were indeed very low for blacks in this period.
} 
Indeed in the segregated South, there were relatively few black schools. ${ }^{26}$ There is also evidence that the South generally allocated very limited funds to black schools, and that those resources were diverted from black to white schools. ${ }^{27}$

Note that the laws affected white males and females equally except for continuation school laws, which only affected males (males in states with continuation school laws obtained about $9 \%$ more education). Since males had more working opportunities than females in this period, they were more likely than females to have obtained a work permit and to be bound by continuation school laws.

The results by gender are interesting for another reason. The 1960 sample might suffer from selection issues, especially for men. For example it might be the case that men with more education were more (or less) likely to die during World War II. Also, war veterans greatly benefited from the GI Bill, which provided financial incentives to go back to school. In order to assess whether the laws are correlated with veteran experience, I estimate the likelihood of being a veteran (for white males only) using a probit model. Controlling for education and all the other state and cohort covariates used in this paper, I find that compulsory schooling laws do not predict veteran status. ${ }^{28}$ Results using only whites in the 1950 census - the Korean War having just begun —are identical(see column 4 of table 4). Finally note that the fact that the coefficients are similar and significant for men and women separately confirms that the war and the post-war events are not a significant source of selection. This is consistent with Bound et al. (1999), who also found that the effects of the GI Bill on educational attainment were small.

\footnotetext{
${ }^{26}$ There were only 64 public high schools in the entire South for black children (from Thomas Jesse Jones, as cited in Margo, 1990, p. 20)

${ }^{27}$ See Card and Krueger (1996), and Margo (1990).

${ }^{28}$ The coefficient on the laws are small and insignificant at the $10 \%$ level.
} 


\section{Why were the laws changed during this period?}

An important question that arises in interpreting these results is: why did the laws change? There are potentially many explanations. One important explanation is that the laws resulted from high levels of education (rather than causing them). Higher enrollment levels facilitate the passage of the laws, since they would encounter less opposition. The laws would affect fewer individuals and expenditures would not have to rise by much as a consequence. We expect therefore that those economic factors that affected education (such as immigration levels, see the introduction) also made the passage of the laws more likely.

Political forces also might affect the passage of the laws. Arguments in the case of Pierce v. the Society of Sisters $(1925)^{29}$ and in Meyer v. Nebraska $(1923)^{30}$ suggest that the politics of compulsory education in the early $20^{\text {th }}$ century are very similar to those in the $19^{\text {th }}$ century. ${ }^{31}$ Those who supported legislation believed that universal education was necessary to promote democracy and to guarantee a common American culture for all, including different immigrant groups, races, and religions. In addition education would lower crime, racism, and inequality, and was necessary for economic growth. These arguments suggest a few reasons why individuals at the lower end of the distribution of education did not choose to obtain higher levels of education: individuals did not anticipate the increases in the returns to education, nor did they perceive the social returns to education, whereas legislators did. ${ }^{32}$

\footnotetext{
${ }^{29}$ In this case, the Supreme Court found Oregon's law that all children ages 8 to 16 attend public schools unconstitutional.

${ }^{30}$ In this case, the Supreme Court declared Nebraska's 1919 law that all instruction be in English unconstitutional.

${ }^{31}$ See Eisenberg (1988) and Butts and Cremin (1953) for a thorough description of the arguments in the $19^{\text {th }}$ century. I found no articles that discuss these issues for compulsory schooling laws for 1914-1939.

${ }^{32}$ It is also possible that there were liquidity constraints. See Card (1995).
} 
In the case of child labor legislation, the main opposition came from the southern states, textile industries, manufacturer's associations, and farmer's organizations. ${ }^{33}$

I predict the changes in the laws as a function of average education level at the state and cohort level, state characteristics, region dummies, state effects, cohort effects and region* cohot effects. As expected, I find (Table 6) that higher wealth (measured by the value of farm per acre) and higher percentages of the immigrant population resulted in more stringent schooling requirements, whereas higher percentage of blacks resulted in lower requirements. This last variable is probably a proxy for southern agricultural states. Higher urbanization affected the entrance age and continuation school passage, but not work permit ages. Unlike Eisenberg, I find that higher per capita expenditures on education did not result in more stringent laws (they are significant only for entrance age, but then they have the wrong sign). Also note that neither manufacturing wages nor the percentage employed in manufacturing had an impact on the laws, which is consistent with the literature which suggests that it was agriculture rather than manufacturing that opposed the passage of the laws.

Like Eisenberg, I find that education levels ${ }^{34}$ in these regressions affected work permit ages (at the 10\% level) and the constructed variable childcom, suggesting indeed there is some potential endogeneity in the previous section. All of the factors that could potentially explain the passage of the laws were included when looking at the impact of the laws on attainment. Their inclusion did not affect the coefficient on the laws much, ${ }^{35}$ suggesting that

\footnotetext{
${ }^{33}$ These groups successfully delayed the passage of federal labor legislation by about 20 years. See Lescohier and Brandeis (1966) pp. 440-450, Kotin and Aikman (1980) pp. 57-64.

${ }^{34}$ Note that education here refers to the average education level eventually obtained by a given cohort as measured in 1960. Alternatively one can use enrollment levels at the time, but that data was not collected for this project. Is is unclear that enrollments would be a better control, since education captures both enrollments and in a sense, projected enrollments, which are just as important.

${ }^{35}$ Results available upon request.
} 
(on the basis of observables) the endogeneity might not be an important issue. The next two sections however will address this issue more in depth, first by looking at the effect of the laws on the entire distribution and then by testing for endogeneity more directly by looking at the timing of the laws.

\section{Effect of the laws on the distribution of education}

There are a few mechanisms through which compulsory schooling may have affected the distribution of education. The standard human capital model predicts that the laws would affect only those below the required level of education; individuals obtaining more than the required level of schooling would not be affected at all. If binding, the laws should have increased average education and decreased educational inequality by increasing the attainment of the lower percentiles of education (Chiswick, 1969).

Additionally, Lang and Kropp (1986) suggested that if individuals at lower levels of education stayed in school because of the laws, then even those not targeted by the laws might have increased their schooling in an effort to differentiate themselves from the bottom (signaling theory of education). So the laws would shift the distribution of education to the right. Note that the shift is most likely smaller at higher levels of education, ${ }^{36}$ so this hypothesis also implies a lower level of inequality.

Finally, if there are option value effects, those that are forced to obtain the required level of schooling might continue their education beyond what the law prescribes, because they now have the option to do so (for example, those that are forced to finish secondary school can now decide to go on to get a high school degree). The distribution of education would therefore be compressed even more than the human capital theory would predict.

\footnotetext{
${ }^{36}$ Lang and Kropp argue that this will be the case if education costs increase at higher levels of education.
} 
Note that the effects on the distribution of education are also suggestive about whether the laws are endogenous or not. A finding that the laws affected all the percentiles of the distribution of education would certainly suggest that the laws are endogenous (e.g. if the entire distribution of education is shifting up only because of increased returns to education, laws forcing children to stay in school are easily passed, and they might appear to affect all percentiles). On the other hand, a finding that the laws only affect the lower percentiles of the distribution is consistent with a model where the laws were enforced and had effects for some children. And less likely to be the result of endogeneity.

As preliminary evidence I plot the evolution of the percentiles of the distribution throughout this period. As can be observed in graph A, the highest increases in education were at the lower percentiles of education. I look now at the effect of the laws on the different percentiles of the distribution of education by estimating regressions where the dependent variable is a given percentile of the distribution for a given state and cohort. I use OLS for a panel of state- and cohort- specific observations (1200 observations derived from the 1960 census, using only whites). As can be seen in Panel A of Table 7 the effect of childlaw is positive and significant for the $10^{\text {th }}, 20^{\text {th }}, 30^{\text {th }}, 40^{\text {th }}$ and $50^{\text {th }}$ percentiles, but not for the higher percentiles (except for the $90^{\text {th }}$ percentile). The effect is strongest for the $40^{\text {th }}$ percentile and it declines for higher percentiles. The $10^{\text {th }}$ to $40^{\text {th }}$ percentiles vary from 5.5 to 11 years of education (again refer to Graph A). The implicit years of education in the laws (as coded in childlaw) were most commonly 6, 7,8 and 9 (see tabulations in Table 2), so this result is consistent with the idea that compulsory education and child labor laws were effective. The fact that the laws affected the $50^{\text {th }}$ percentile can be understood as evidence for the signaling theory of education, as well as for the "option value" theory. 
Alternatively I ran the regressions using the percentage of individuals with a given level of education or less in a given state and cohort. The results (Table 7, Panel B) show that the laws lowered the percentage of individuals obtaining 10 or less years of schooling (the largest effect is for 8 and 9 years of schooling). But the effect remains stable or falls if I include those with 11 years of education or more. Results in both Panels of Table 7 suggest the laws were effective at and around the age specified by the laws, consistent with the effects predicted by the human capital theory and both the signaling and option value theory. But they are inconsistent with the endogeneity theory.

The results above also suggest that compulsory schooling laws lowered inequality in education since they increased the education level only of those at the bottom of the distribution. To evaluate this hypothesis I decompose the variance of education into the effects of shifts in composition (i.e. the number of individuals living under a given law), and the shifts in education within and between law categories (see Juhn, Murphy and Pierce, 1993.) The total decline in the variance of education from 1915 to 1939 was 2.52. Panel A of Table 8 shows that in fact a very large part of this decline in the variance can be explained by changes in the number of individuals living under given laws (i.e. composition effects). But note that since these changes in composition are due to many factors, these calculations are merely suggestive.

So, I now estimate the effect of the laws on inequality using the $75-25$ range $^{37}$ and the variance of education as measures of inequality using regression analysis, and controlling for all the other state-level characteristics. The results (Panel B Table 8) show that the effect of childlaw on the 75-25 range is negative and significant. The effect on the variance is negative 
but not statistically significant. During this period, the interquartile range (75-25 range) fell by approximately 1.5 years (from 4.3 in 1915 to 2.83 in 1939), the variance of education fell by 2.5 and childcom increased by a little more than 2 years. The regression coefficients imply that about $14 \%$ of the decline in the interquartile range and $6 \%$ of the decline in the variance can be explained by the changes in compulsory schooling and child labor laws. The effect is larger for the interquartile range because it does not capture the shifts in the $90^{\text {th }}$ percentile.

Note that Goldin and Margo (1992) find that the variance in school quality also declined during the first half of the $20^{\text {th }}$ century. These two effects (decreasing variance of school attainment and of school quality) might indeed be related: by passing compulsory schooling laws states forced themselves to provide public schools, and thus to raise the level of educational expenditures (to both enforce the laws and guarantee school availability).

\section{Were the laws endogenous?}

Although most researchers find that the laws positively affected education levels, they are skeptical to conclude that the effect is causal. As has been pointed out in section 4 and 5 , it is possible that higher enrollments permitted higher minimum ages to be instituted by the legislature - causality could thus run from education to the laws and not vice-versa.

States where attainment was high were also probably states where the laws were stringent: individuals in those states might have stronger preferences for education. Indeed, Goldin and Katz (1997) show that the Far West, the Great Plains, and parts of New England led in secondary education from 1910 to 1940 , while the South lagged. Those regions also had more stringent laws (Panel A Table 9). Therefore a first attempt to address this issue consists in estimating separate regressions by region (Panel B Table 9). The effect of

\footnotetext{
${ }^{37}$ This interquartile measure seems the most appropriate for a couple of reasons. First, the results above suggest that the largest effects were not at the absolute bottom of the distribution (i.e. the $10^{\text {th }}$ percentile). Also note that
} 
childlaw on education is still significant, although it was much larger in the North than anywhere else, and it is insignificant in the West. Interestingly, continuation school laws were effective in the northern and southern states but not in the rest of the country. The results suggest that although there were indeed large differences within the US, the laws were effective within regions as well. However it is still possible that even within regions there were important differences between states.

Landes and Solomon - the only researchers that address directly this endogeneity issue, propose an alternative test: if the laws are truly exogenous, then laws passed in a given year should not explain the level of enrollments ten years earlier. They estimate 1870 enrollment levels using the 1880 laws as explanatory variables, and they find that the 1880 laws are significant and therefore endogenous.

To perform this test I follow Landes and Solomon and estimate the effect of future laws on current attainment by matching individuals both to laws that were in place when they were 14 and to laws that were in place when they were too old to have been affected by them. I therefore estimate two equations: one that includes the current law and a second that includes the future law. Unlike Landes and Solomon, I match individuals to laws not only 10 years into the future but to every period between $3^{38}$ and 12 years ahead. I examine the effect on the educational attainment of people who were 14 in 1925 of laws passed in 1925, and of laws passed in 1928, 1929, etc. when they were 15, 16, 17...24 and laws governing attendance at 14 should no longer have affected their educational attainment (Landes and Solomon use a 10 year lead because their estimates compare cohorts across decennial

\footnotetext{
the effect of the laws on the $90^{\text {th }}$ percentile is positive and significant: it is unclear why this is the case.

${ }^{38}$ No states had set work permit ages at age 17 . Therefore matching individuals to the laws that were in place at that age should have no effect. The same is not true for ages 15 and 16 , since some states did have work permit for those ages (see Table 2).
} 
censuses). So, in Table 10, the row labeled "3 years", childlaw refers to the current laws, and future childlaw refers to the laws passed three years later. I estimate these regressions at the state and cohort level, and restrict the sample to those states for which there were changes during the time interval. Regardless of the time span chosen (except for the 10-year span) the current laws are always significant whereas the future laws are not. When L\&S perform this test, they find that laws passed 10 years after an individual's effective age are correlated with attainment. When I perform this test, I find that laws passed 3-9, 11, or 12 years later are not correlated with attainment. Interestingly, these results also suggest that the laws were relatively more effective in the earlier part of the period. ${ }^{39}$

Curiously, I do find an effect when I use a ten-year lead. Age misreporting could explain this result. Oppenheim and Cope (1987) show that in the 1900 census when age and birth date do not coincide (and the difference between them is more than one year), $75 \%$ of the time the reported age and the age implied by the date of birth will differ by $10,20,30$ or 40 years. Their results further suggest these discrepancies occur because census interviewers recorded the wrong leading digit of age or decade of birth. Measurement error in age might therefore explain Landes and Solomon's results since this problem was more severe in the last century.

\section{Conclusions}

This paper has shown that there were two types of laws that contributed to the increase in educational attainment from 1915 to 1939: the laws which specified the age at which a child had to enter school, and the laws which specified the age at which a child could obtain a work permit. Increasing the number of years a child had to attend school was shown

\footnotetext{
${ }^{39}$ The coefficient on the current law is increasing as the sample is restricted. As the lead increases, the observations kept in the sample correspond to older cohorts.
} 
to increase years of education by about $5 \%$. These laws affected white men and women equally but had no effect on blacks. They were more effective in the southern and northern states than in the rest of the country. Continuation school laws, which forced working children to attend school on a part-time basis, affected only white males and those born in the northern and southern states of the US. The laws had an impact not only on average educational attainment but also on the distribution of education as a whole. They substantially contributed to the decrease of educational inequality by increasing the education level of the lower percentiles of the distribution of education. Not only were these laws effective, this paper has also shown that these laws were not endogenous during the 19151939 period.

\section{References}

Acemoglou, Daron and Joshua Angrist, "How Large are the Social Returns to Education? Evidence from Compulsory schooling Laws," NBER Working Paper No. W7444, December 1999

Angrist, Joshua D. and Alan B. Krueger, "Does Compulsory School Attendance Affect Schooling and Earnings?," Quarterly-Journal-of-Economics;106(4), November 1991

Bound, John and David A. Jaeger, "On the Validity of Season of Birth as an Instrument in Wage Equations: A Comment on Angrist \& Krueger's 'Does Compulsory School Attendance Affect Schooling?',” NBER Working Paper No. W5835, Issued in November 1996

Bound, John and Sarah E. Turner, "Going to War and Going to College: Did World War II and the G.I. Bill Increase Educational Attainment for Returning Veterans?," NBER Working Paper No. W7452, December 1999

Butts, Freeman R and Lawrence A Cremin, "A History of Education in American Culture," Teachers College, Columbia University, 1953

Card, David, "Estimating the Returns to Schooling: Progress on some Persistent Econometric Problems," NBER Working Paper no. W7769, June 2000

Card, David E. and Alan Krueger, "School Resources and Student Outcomes: An Overview of the Literature and New Evidence from North and South Carolina," Journal of Economic Perspectives, vol. 10, Fall 1996 
, "Does School Quality Matter? Returns to Education and the Characteristics of Public Schools in the United States," Journal of Political Economy 100, January 1992

---o---o "School Quality and Black-White Relative Earnings: A Direct Assessment," Quarterly Journal of Economics, Vol. 107, No. 1., February 1992, pp. $151-200$

Chiswick, Barry R., "Minimum Schooling Legislation and the cross-sectional Distribution of Income," Economic-Journal; 79(315), Sept. 1969

Edwards, Linda N., "An Empirical Analysis of Compulsory Schooling Legislation, 19401960," Journal of Law and Economics; 21(1), April 1978

Eisenberg, M.J. (1988) "Compulsory Attendance legislation in America, 1870 to 1915," Ph.D. Dissertation, University of Pennsylvania

Ensign, Forest Chester, "Compulsory School Attendance and Child Labor," Iowa City, IA: The Athens press, 1921

Goldin, Claudia, "How America Graduated From high School: 1910 to 1960: NBER Working Paper No 4762, 1994

1994

, "Appendix to 'How America Graduated From high Historical Paper No 57, "Household and Market Production of Families in Late Nineteenth Century American City," Explorations in Economic History 16, 111-131, 1971

Goldin, Claudia and Lawrence Katz, "Why the United States Led on Education: Lessons from Secondary School Expansion, 1910 to 1940," NBER Working Paper 6144, August 1997

Goldin, Claudia and Robert A. Margo, "The Great Compression: The Wage Structure in the United States at Mid- Century," Quarterly Journal of Economics, Vol. 107, No. 1. (Feb., 1992), pp. 1-34.

Katz, Michael, “A History of Compulsory Education Laws," Phi Delta Kappa Educational Foundation 1976

Kern, Alexander and K. Forbis Jordan, "Legal Aspects of Educational Choice: Compulsory Attendance and Student Assignment," Topeka, KS: National Organization on Legal Problems of Education, 1973 
Kotin, Lawrence and William F. Aikman, Legal Foundations of Compulsory Schooling, Port Washington, NY: Kennikat Press 1980

Landes William and Lewis C. Solomon, "Compulsory Schooling Legislation: An economic Analysis of Law and Social Change in the Nineteenth Century," Journal of Economic History; 22(1), March 1972

Lang, Kevin and David Kropp, "Human Capital versus Sorting: The Effects of Compulsory Attendance Laws," Quarterly-Journal-of-Economics; 101(3), August 1986

Margo, Robert A., Race and Schooling in the South: 1880-1950, Chicago: University of Chicago Press, 1990

Margo, Robert A. and T. Aldrich Finegan, "Compulsory Schooling Legislation and School Attendance in Turn-of-The Century America: A 'Natural Experiment'," Economics-Letters; 53(1), October 1996

Moehling, Carolyn M., "State Child Labor Laws and the Decline of Child Labor," Explorations in Economic History 36, 72-106, 1999

Oppenheim Mason, Karen and Lisa G. Cope, "Sources of Age and Date-of-Birth Misreporting in the 1900 U.S. Census," Demography, Vol. 24, No. 4. (Nov., 1987), pp. 563573

Schmidt, Stefanie, "School Quality, Compulsory Education Laws, and the Growth of American High School Attendance, 1915-1935," MIT Ph.D. Dissertation 1996

Stigler, George, "Employment and Compensation in Education," NBER Occasional Paper. Number 53. 1950

Tyack, David One Best system: A History of American Urban Education. Harvard University Press. Cambridge, Massachusetts, 1974

Welch, Finis, "Black-White Differences in Returns to Schooling," American Economic Review 63, 893-907, 1973

Woltz, Charles, K., "Compulsory Attendance at School," in Law and Contemporary Problems, School of Law, Duke University Vol. 20 Winter 1955, No. 1 


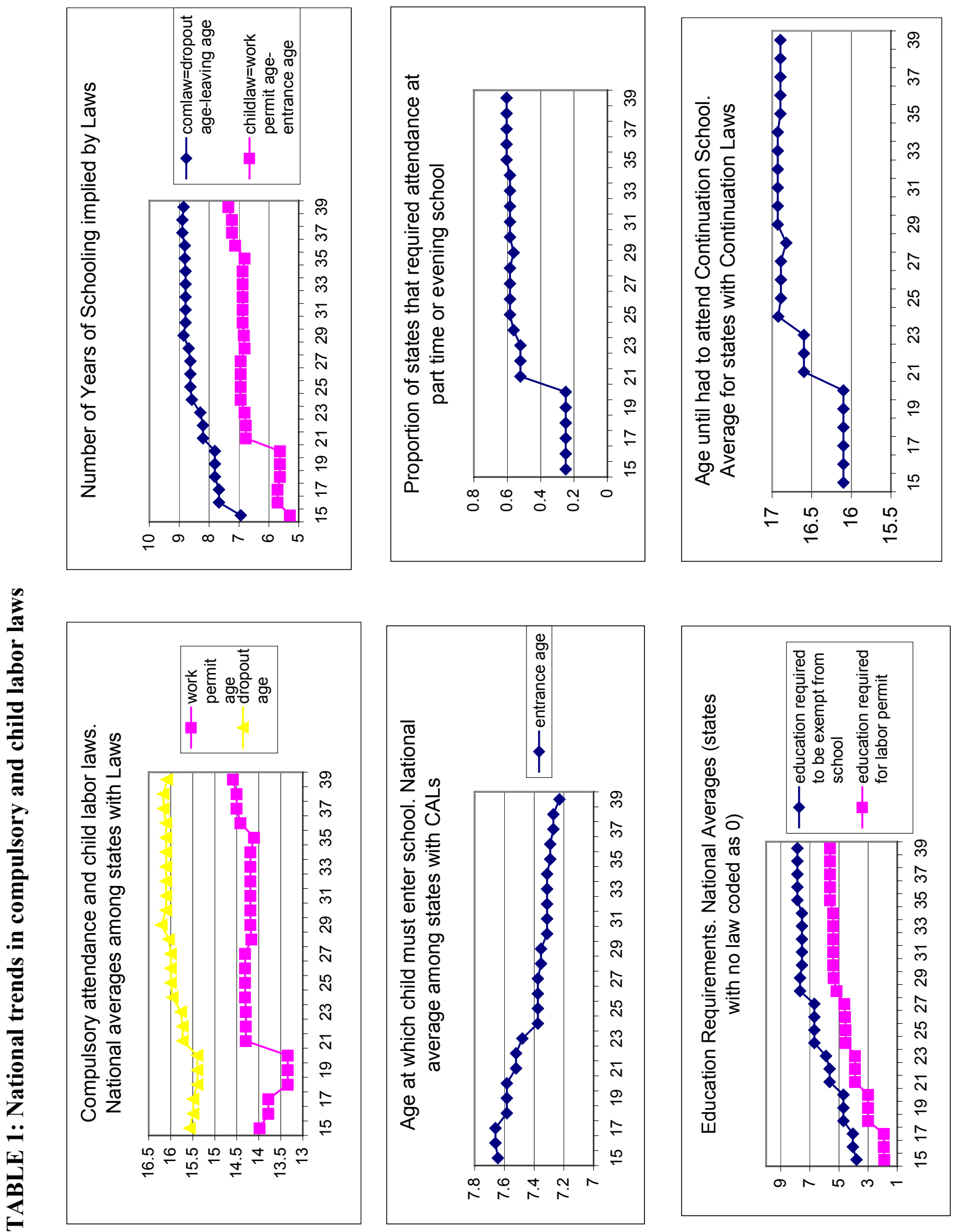



\section{TABLE 2: Tabulations of Laws Across States}

\section{Compulsory Attendance Laws}

\begin{tabular}{|c|c|c|c|}
\hline \multicolumn{4}{|c|}{ Age at which } \\
\hline & 1915 & 1928 & 1939 \\
\hline 6 & 0 & 2 & 2 \\
\hline 7 & 16 & 28 & 33 \\
\hline 8 & 25 & 17 & 13 \\
\hline 9 & 1 & 1 & 0 \\
\hline
\end{tabular}

\begin{tabular}{|c|c|c|c|}
\hline \multicolumn{4}{|c|}{$\begin{array}{l}\text { Age at which can } \\
\text { Dropout of school }\end{array}$} \\
\hline & 1915 & 1928 & 1939 \\
\hline 12 & 2 & & \\
\hline 14 & 4 & 5 & 4 \\
\hline 15 & 8 & 3 & 1 \\
\hline 16 & 26 & 30 & 35 \\
\hline 17 & 0 & 5 & 3 \\
\hline 18 & 1 & 5 & 5 \\
\hline 20 & 1 & & \\
\hline Total & 42 & 48 & 48 \\
\hline
\end{tabular}

\begin{tabular}{|c|c|c|c|}
\hline \multicolumn{4}{|c|}{$\begin{array}{l}\text { Education required } \\
\text { to be exempt }\end{array}$} \\
\hline & 1915 & 1928 & 1939 \\
\hline 0 & 24 & 3 & 3 \\
\hline 4 & 1 & 0 & 0 \\
\hline 5 & 0 & 1 & 1 \\
\hline 6 & 2 & 2 & 2 \\
\hline 7 & 2 & 1 & 4 \\
\hline 8 & 19 & 37 & 31 \\
\hline 12 & 0 & 4 & 7 \\
\hline Total & 48 & 48 & 48 \\
\hline
\end{tabular}

\section{Child Labor Laws}

\begin{tabular}{|c|c|c|c|}
\hline \multicolumn{4}{|c|}{ Minimun age to get work permit } \\
\hline & 1915 & 1928 & 1939 \\
\hline 12 & 2 & & \\
\hline 13 & 1 & & \\
\hline 14 & 38 & 42 & 32 \\
\hline 15 & 4 & 4 & 4 \\
\hline 16 & 0 & 2 & 12 \\
\hline Total & 45 & 48 & 48 \\
\hline
\end{tabular}

\begin{tabular}{|c|c|c|c|}
\hline \multicolumn{4}{|c|}{ Education required for work permit } \\
\hline & 1915 & 1928 & 1939 \\
\hline 0 & 33 & 12 & 10 \\
\hline 4 & 1 & 2 & 2 \\
\hline 5 & 5 & 4 & 3 \\
\hline 6 & 5 & 8 & 8 \\
\hline 7 & 1 & 4 & 2 \\
\hline 8 & 3 & 18 & 23 \\
\hline Total & 48 & 48 & 48 \\
\hline
\end{tabular}

\section{Continuation School Laws}

\begin{tabular}{|c|c|c|c|}
\hline \multicolumn{4}{|c|}{ Have Continuation School Laws } \\
\hline & 1915 & 1928 & 1939 \\
\hline 0 & 36 & 20 & 19 \\
\hline 1 & 12 & 28 & 29 \\
\hline Total & 48 & 48 & 48 \\
\hline
\end{tabular}

\begin{tabular}{cccc}
\hline \hline \multicolumn{4}{c}{ Age until must continue continuation school } \\
\hline & 1915 & 1928 & 1939 \\
\hline 16 & 9 & 16 & 15 \\
17 & 1 & 1 & 2 \\
18 & 0 & 11 & 12 \\
\hline Total & 10 & 28 & 29 \\
\hline
\end{tabular}

\section{Constructed variables: Number of years}

\begin{tabular}{|c|c|c|c|}
\hline \multicolumn{4}{|c|}{ Childlaw $=$ work age - enter age } \\
\hline & 1915 & 1928 & 1939 \\
\hline 0 & 8 & & \\
\hline 4 & 1 & & \\
\hline 5 & 2 & 1 & \\
\hline 6 & 21 & 15 & 9 \\
\hline 7 & 14 & 26 & 23 \\
\hline 8 & 2 & 5 & 7 \\
\hline 9 & & & 8 \\
\hline 10 & & 1 & 1 \\
\hline Total & 48 & 48 & 48 \\
\hline
\end{tabular}

\begin{tabular}{|c|c|c|c|}
\hline \multicolumn{4}{|c|}{ Comlaw $=$ Leave age - enter age } \\
\hline & 1915 & 1928 & 1939 \\
\hline 0 & 6 & & \\
\hline 4 & 2 & & \\
\hline 6 & 2 & 4 & \\
\hline 7 & 6 & 2 & 4 \\
\hline 8 & 21 & 12 & 11 \\
\hline 9 & 9 & 20 & 25 \\
\hline 10 & 1 & 8 & 5 \\
\hline 11 & & 1 & 2 \\
\hline 12 & 1 & 1 & 1 \\
\hline Total & 48 & 48 & 48 \\
\hline
\end{tabular}


TABLE 3: Effect of Compulsory Attendance And Child Labor Laws on Education

\begin{tabular}{|c|c|c|c|c|c|c|c|}
\hline Variables & & (1) & (2) & (3) & (4) & (5) & (6) \\
\hline \multicolumn{8}{|c|}{ Dependent Variable Education } \\
\hline \multirow[t]{14}{*}{ Education Laws } & Age at which must enter school & & & $-0.048^{* *}$ & & & $-0.045^{*}$ \\
\hline & & & & $(0.022)$ & & & $(0.024)$ \\
\hline & Age at which can dropout of school & & & & & & $\begin{array}{l}0.005 \\
(0.015)\end{array}$ \\
\hline & Comlaw $=$ Leaving age - entering age & & & & 0.008 & 0.008 & \\
\hline & & & & & $(0.009)$ & $(0.009)$ & \\
\hline & Education required to dropout & & & & & 0.000 & 0.000 \\
\hline & & & & & & $(0.004)$ & $(0.004)$ \\
\hline & Age for Work Permit & & & $0.065^{* *}$ & & & \\
\hline & & & & $(0.011)$ & & & \\
\hline & Childlaw $=$ Work age - Enter age & $\begin{array}{c}0.051^{* *} \\
(0.01)\end{array}$ & $0.050^{* *}$ & & & & \\
\hline & Education Required for Work permit & & 0.004 & 0.005 & & & \\
\hline & & & $(0.004)$ & $(0.004)$ & & & \\
\hline & Continuation School required $(=1)$ & 0.047 & 0.048 & 0.046 & 0.024 & 0.024 & 0.025 \\
\hline & & $(0.038)$ & $(0.037)$ & $(0.037)$ & $(0.038)$ & $(0.038)$ & $(0.038)$ \\
\hline \multirow{8}{*}{$\begin{array}{c}\text { Individual } \\
\text { characteristics }\end{array}$} & Female & $0.186^{* *}$ & $0.186^{* *}$ & $0.183^{* *}$ & $0.186^{* *}$ & $0.186^{* *}$ & $0.182^{* *}$ \\
\hline & & (0.019) & $(0.019)$ & $(0.019)$ & $(0.019)$ & $(0.019)$ & $(0.019)$ \\
\hline & Black & $-2.109 * *$ & $-2.109 * *$ & $-2.083 * *$ & $-2.109 * *$ & $-2.109 * *$ & $-2.083 * *$ \\
\hline & & $(0.045)$ & $(0.045)$ & $(0.045)$ & $(0.045)$ & $(0.045)$ & $(0.045)$ \\
\hline & Other Race & $-1.714 * *$ & $-1.714 * *$ & $-1.698 * *$ & -1.714 & $-1.714 * *$ & $-1.714 * *$ \\
\hline & & $(0.187)$ & $(0.187)$ & $(0.188)$ & $(0.188)$ & $(0.188)$ & $(0.187)$ \\
\hline & Parents foreign born & $-0.763 * *$ & $-0.763 * *$ & $-0.761 * *$ & -0.763 & $-0.763 * *$ & $-0.761 * *$ \\
\hline & & $(0.028)$ & $(0.028)$ & $(0.029)$ & $(0.029)$ & $(0.029)$ & $(0.029)$ \\
\hline \multirow{21}{*}{$\begin{array}{l}\text { State-of-Birth } \\
\text { Characteristics }\end{array}$} & $\%$ Urban & $0.028^{* *}$ & $0.028^{* *}$ & $0.027 * *$ & $0.031 * *$ & $0.032^{* *}$ & $0.032^{* *}$ \\
\hline & & $(0.005)$ & $(0.006)$ & $(0.006)$ & $(0.006)$ & $(0.006)$ & $(0.006)$ \\
\hline & $\%$ Foreign & 0.014 & 0.014 & 0.013 & 0.019 & 0.019 & 0.015 \\
\hline & & $(0.011)$ & $(0.011)$ & $(0.012)$ & $(0.012)$ & $(0.011)$ & $(0.012)$ \\
\hline & $\%$ Black & 0.000 & -0.001 & -0.005 & -0.003 & -0.003 & -0.007 \\
\hline & & $(0.010)$ & $(0.010)$ & $(0.011)$ & $(0.010)$ & $(0.010)$ & $(0.011)$ \\
\hline & $\%$ Employed in manufacturing & -0.589 & -0.534 & -0.818 & -0.954 & -0.954 & -1.318 \\
\hline & & $(0.527)$ & $(0.525)$ & $(0.672)$ & $(0.540)$ & $(0.540)$ & $(0.638)$ \\
\hline & Annual Manufacturing wage & 0.000 & 0.000 & 0.000 & 0.000 & 0.000 & 0.000 \\
\hline & & $(0.000)$ & $(0.000)$ & $(0.000)$ & $(0.000)$ & $(0.000)$ & $(0.000)$ \\
\hline & Value of farm per acre & 0.000 & 0.000 & 0.000 & 0.000 & 0.000 & 0.000 \\
\hline & & $(0.000)$ & $(0.000)$ & $(0.000)$ & $(0.000)$ & $(0.000)$ & $(0.000)$ \\
\hline & Per capita number of doctors & $165.51 *$ & $162.89 *$ & $162.05^{*}$ & $204^{*}$ & $203.31 *$ & $192.49^{*}$ \\
\hline & & $(96.248)$ & $(96.089)$ & (96.287) & $(105.89)$ & $(105.72)$ & (102.43) \\
\hline & Per capita education expenditures & $0.001 * *$ & $0.001^{* *}$ & $0.001^{* *}$ & $0.001 * *$ & $0.001^{* *}$ & $0.001^{* *}$ \\
\hline & & $(0.000)$ & $(0.000)$ & $(0.000)$ & $(0.000)$ & $(0.000)$ & $(0.000)$ \\
\hline & Number of school buildings per sq. mile & -0.012 & -0.069 & -0.097 & -0.289 & -0.295 & -0.198 \\
\hline & & $(0.336)$ & $(0.340)$ & $(0.339)$ & $(0.346)$ & $(0.351)$ & $(0.353)$ \\
\hline & R-Squared & 0.15 & 0.15 & 0.1458 & 0.1499 & 0.1499 & 0.146 \\
\hline & $\mathrm{N}$ & 478591 & 478591 & 475049 & 478591 & 478591 & 475366 \\
\hline & F-statistic on laws & $13.58^{* *}$ & $9.26 * *$ & $9.92 * *$ & 0.60 & 0.4 & 1.24 \\
\hline
\end{tabular}

All regressions include state-of-birth dummies, cohort dummies region-of-birth*cohort dummies and an intercept. Standard errors (in parenthesis) are clustered at the state-of-birth and cohort level.

** significant at $5 \%$, significant at $10 \%$. 
TABLE 4: Effect of Laws on Education. Specification Checks

\begin{tabular}{|c|c|c|c|c|c|}
\hline & & $\begin{array}{l}\text { States with } \\
\text { laws only }\end{array}$ & 8 cohorts & Non-movers & $\begin{array}{c}1950 \\
\text { Census }\end{array}$ \\
\hline Dependent variable & Education & & & & \\
\hline \multirow[t]{5}{*}{$\begin{array}{l}\text { Education } \\
\text { Laws }\end{array}$} & Childlaw $=$ Work age-enter age & $\begin{array}{l}0.062^{* *} \\
(0.010)\end{array}$ & $\begin{array}{r}0.048^{* *} \\
(0.017)\end{array}$ & $\begin{array}{r}0.042^{* *} \\
(0.009)\end{array}$ & $\begin{array}{r}0.046^{* *} \\
(0.014)\end{array}$ \\
\hline & Continuation School Required $(=1)$ & $\begin{array}{c}0.044 \\
(0.037)\end{array}$ & $\begin{array}{c}0.083 \\
(0.063)\end{array}$ & $\begin{array}{c}0.056 \\
(0.036)\end{array}$ & $\begin{array}{r}0.058 \\
(0.053)\end{array}$ \\
\hline & R-Squared & 0.1458 & 0.1569 & 0.1576 & 0.1538 \\
\hline & Number of observations & 475049 & 151553 & 306299 & 152270 \\
\hline & F-statistic on Laws & $19.26^{* *}$ & $4.69 * *$ & $10.08^{* *}$ & $6.18^{* *}$ \\
\hline
\end{tabular}

Standard errors (in parenthesis) are robust. All coefficients derived from regressions that use the same controls as in Table 3 .

** significant at $5 \%,{ }^{*}$ significant at $10 \%$ 


\section{TABLE 5: Effect of Laws on Education by gender and race}

\begin{tabular}{|c|c|c|c|c|c|}
\hline \multicolumn{2}{|l|}{ Variables } & White males & White females & Black males & Black females \\
\hline $\begin{array}{c}\text { Dependent } \\
\text { Variable }\end{array}$ & Education & & & & \\
\hline $\begin{array}{l}\text { Education } \\
\text { laws }\end{array}$ & Childlaw $=$ Work age-enter age & $\begin{array}{c}0.046^{* *} \\
(.014)\end{array}$ & $\begin{array}{c}0.062 * * \\
(.011)\end{array}$ & $\begin{array}{l}0.014 \\
(.028)\end{array}$ & $\begin{array}{r}-0.023 \\
(.022)\end{array}$ \\
\hline & Continuation School Required $(=1)$ & $\begin{array}{c}0.085 * \\
(.050)\end{array}$ & $\begin{array}{l}0.004 \\
(.043)\end{array}$ & $\begin{array}{l}0.039 \\
(.158)\end{array}$ & $\begin{array}{l}0.104 \\
(.119)\end{array}$ \\
\hline
\end{tabular}

Standard errors (in parenthesis) are robust. All coefficients derived from regressions that use the same controls as in Table 3.

** significant at 5\%, * significant at $10 \%$. 
TABLE 6: Why were the laws passed?

\begin{tabular}{lcccc}
\hline \hline \multicolumn{1}{c}{ Dependent variable } & $\begin{array}{c}\text { Work Permit } \\
\text { age }\end{array}$ & Entrance Age & $\begin{array}{c}\text { Continuation } \\
\text { School }\end{array}$ & $\begin{array}{c}\text { Childcom=Work } \\
\text { age-enter age }\end{array}$ \\
\hline Independent variables & & & & \\
Education & $0.176^{*}$ & -0.034 & 0.022 & $0.392^{* *}$ \\
\% urban & $(0.104)$ & $(0.0309)$ & $(0.021)$ & $(0.135)$ \\
& 0.011 & $-0.017^{* *}$ & $0.020^{* *}$ & 0.036 \\
\% foreign & $(0.017)$ & $(0.007)$ & $(0.004)$ & $(0.024)$ \\
\% black & -0.019 & $-0.058^{* *}$ & 0.005 & $0.102^{* *}$ \\
& $(0.025)$ & $(0.013)$ & $(0.009)$ & $(0.040)$ \\
\% employed in manufacturing & $-0.112^{* *}$ & $-0.040^{* *}$ & $0.084^{* *}$ & $-0.202^{* *}$ \\
Annual Manufacturing wage & $(0.045)$ & $(0.015)$ & $(0.011)$ & $(0.063)$ \\
& -2.891 & -0.844 & 0.201 & -5.662 \\
Value of farm per acre & $(2.848)$ & $(1.044)$ & $(0.586)$ & $(3.662)$ \\
Per capita number of doctors & 0.000 & 0.000 & 0.000 & 0.000 \\
& $(0.000)$ & $(0.000)$ & $(0.000)$ & $(0.000)$ \\
Per capita expenditures on education & $0.001^{* *}$ & $-0.001^{* *}$ & $0.000^{*}$ & $0.002^{* *}$ \\
& $(0.000)$ & $(0.000)$ & $(0.000)$ & $(0.001)$ \\
\# of school buildings per sq. mile & 44.740 & $-187.7^{* *}$ & $207.19^{* *}$ & -83.562 \\
& $(222.909)$ & $(85.549)$ & $(105.538)$ & $(298.50)$ \\
& 0.000 & $0.001^{* *}$ & 0.000 & -0.000 \\
& $(0.001)$ & $(0.000)$ & $(0.000)$ & $(0.002)$ \\
& -1.495 & $2.588^{* *}$ & $2.238^{* *}$ & $-5.777^{* *}$ \\
& $(1.131)$ & $(0.773)$ & $(0.426)$ & $(1.699)$ \\
& & & & 0.562 \\
\hline
\end{tabular}

All regressions include state-of-birth dummies, cohort dummies region-of-birth*cohort dummies and an intercept. Standard errors (in parenthesis) are clustered at the state-of-birth and cohort level.

** significant at $5 \%, *$ significant at 10 . 


\section{Graph A}

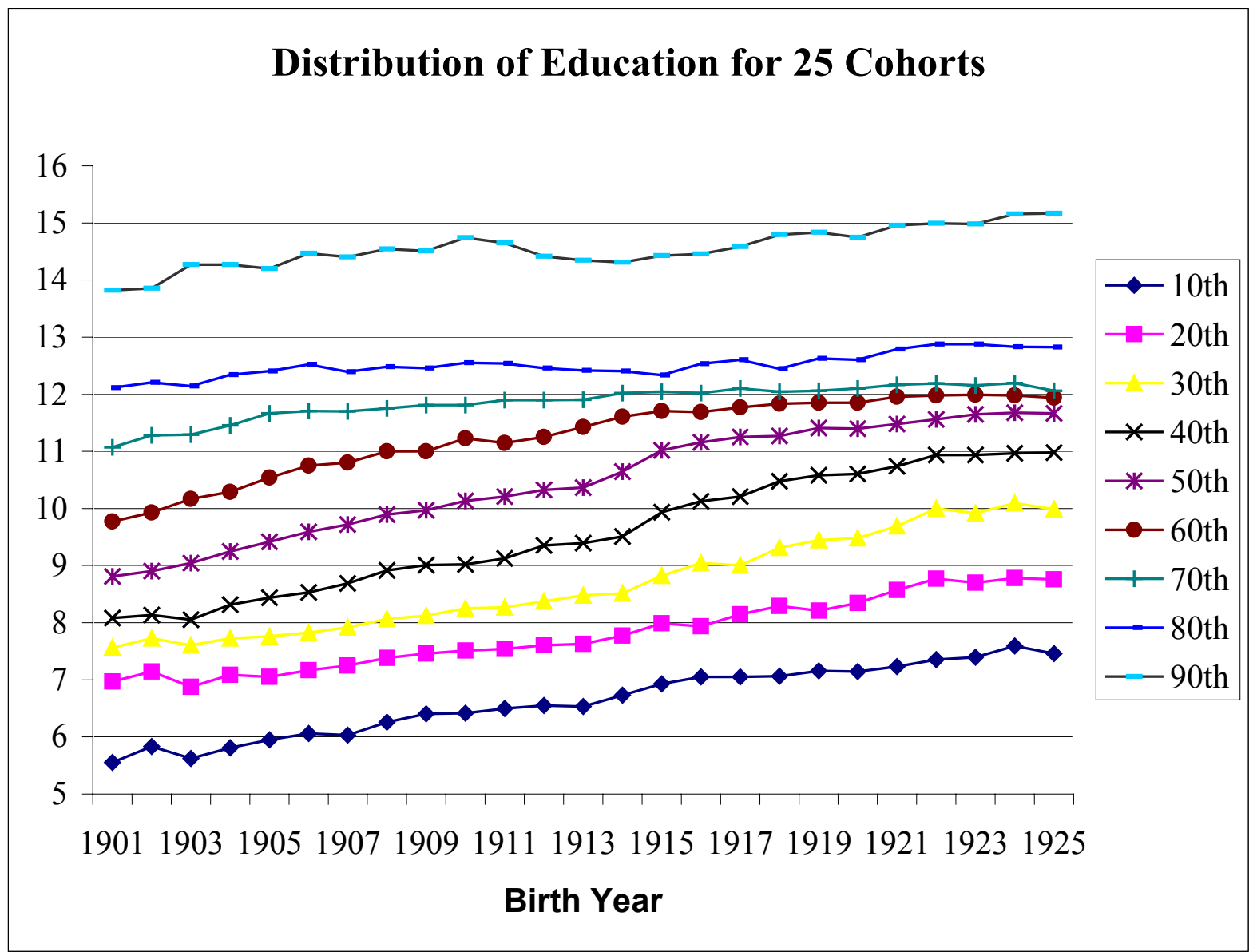

Note: In this graph the $i^{\text {th }}$ percentile refers to the average $i^{\text {th }}$ percentile across states rather than to the $i^{\text {th }}$ percentile of the entire U.S. distribution. 


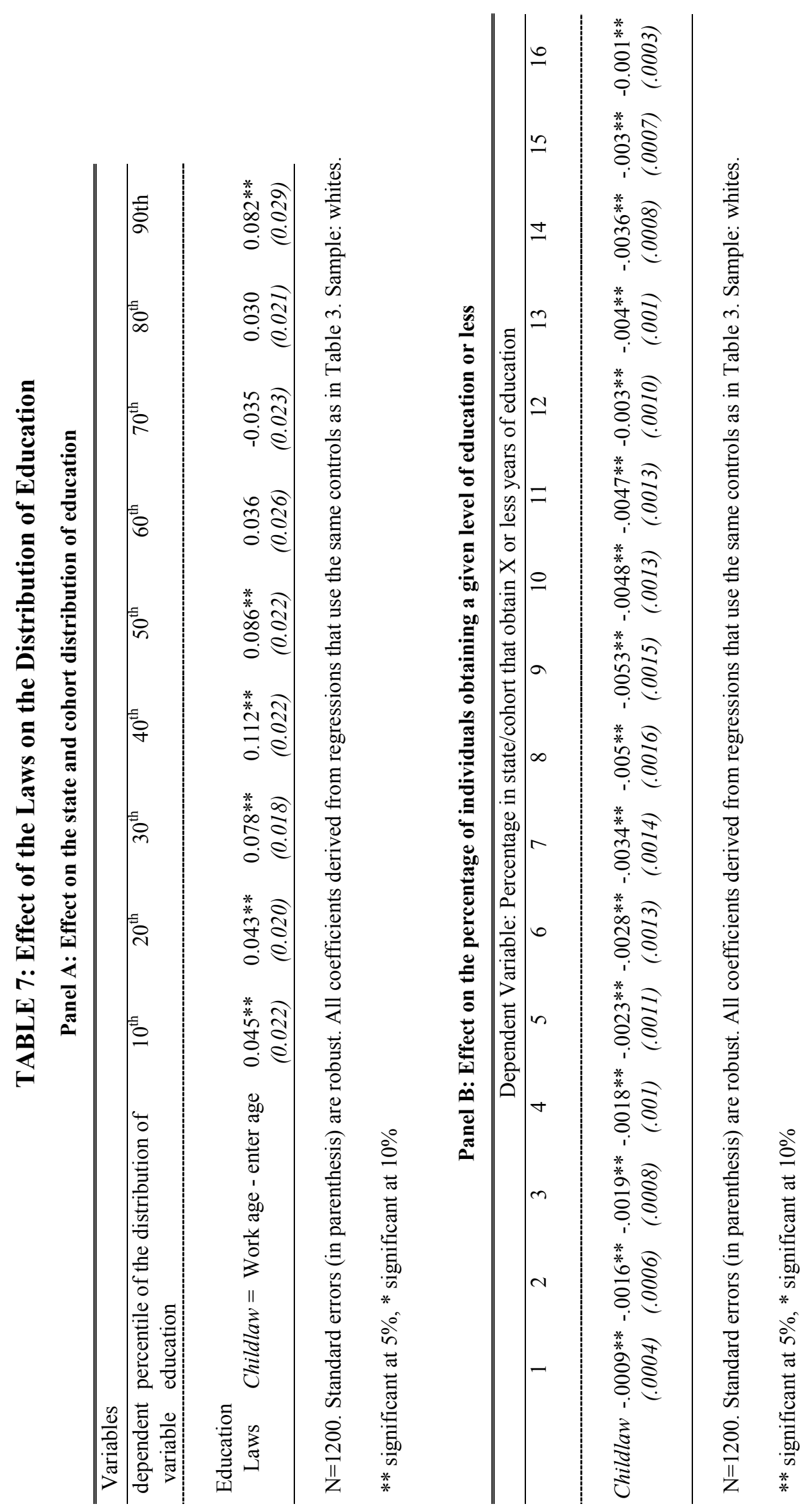




\section{TABLE 8: Effects of the distribution of compulsory schooling laws on inequality}

Panel A: Within and between decomposition of the variance in education

\begin{tabular}{cccccc}
\hline \hline & \multicolumn{2}{c}{ Within variation } & & \multicolumn{2}{c}{ Between variation } \\
\cline { 2 - 3 } \cline { 5 - 6 } total change & variance effect & composition effect & & education changes & composition effect \\
\cline { 2 - 3 } \cline { 5 - 6 }-2.522512 & -3.664 & 1.339567 & & 22.82157 & -23.02284 \\
\hline
\end{tabular}

Notes: These calculations were computed as follows:

$\left(\sigma_{t+1}^{2}-\sigma_{t}^{2}\right)=\sum_{i} P_{i t}\left(\sigma_{i t+1}^{2}-\sigma_{i t}^{2}\right)+\sum_{i} \sigma_{i t+1}^{2}\left(P_{i t+1}-P_{i t}\right)+\sum_{i} P_{i t}\left(\Delta e_{i t+1}^{2}-\Delta e_{i t}^{2}\right)+\sum_{i} \Delta e_{i t+1}^{2}\left(P_{i t+1}-P_{i t}\right)$

where $\sigma_{t}^{2}$ is the variance of education for cohort $t, P_{i t}$ is the proportion of individuals under compulsory law i in cohort $t$, and $\Delta \mathrm{e}_{t}^{2}=\left(\mathrm{e}_{\mathrm{it}}\right.$ $\left.-e_{t}\right)^{2}$, where $e_{t}$ is the average level of education for cohort $t$. The first sum in the expression is the variance effect, the second sum is the composition effect. The first and second sums constitute the total within variation change. The third sum captures changes in education. The third term captures changes in $\mathrm{P}_{\mathrm{it}}$ so again this is a composition effect. The third and fourth sums constitute the total between variation.

Panel B: Effect of the laws on inequality measures using regression analysis

\begin{tabular}{cccc}
\hline \hline Variables & & & \\
\hline Dependent variable & percentile of the distribution of education & $75-25$ Range & Education Variance \\
Laws & Childlaw $=$ Work age - enter age & $-0.093 *$ & -0.079 \\
& & $(0.023)$ & $(0.058)$ \\
\hline
\end{tabular}

Standard errors (in parenthesis) are robust. All coefficients derived from regressions that use the same controls as in Table 3. Sample:Whites.

** significant at 5\%, * significant at $10 \%$. 


\section{TABLE 9: Results by Region}

\begin{tabular}{|c|c|c|c|c|c|}
\hline Variables & & South & North & Midwest & West \\
\hline \multirow{8}{*}{ Laws } & \multicolumn{5}{|c|}{ Panel A: Means } \\
\hline & Education & 8.924 & 10.564 & 10.748 & 10.988 \\
\hline & 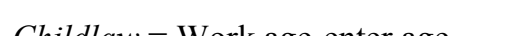 & & 6020 & 7067 & 6261 \\
\hline & Childlaw $=$ Work age-enter age & 0.283 & 6.929 & 7.067 & 6.364 \\
\hline & Work Age & 13.822 & 14.302 & 14.267 & 14.278 \\
\hline & Enter Age & 7.413 & 7.373 & 7.200 & 7.676 \\
\hline & Continuation School Required $(=1)$ & 0.273 & 0.556 & 0.607 & 0.662 \\
\hline & \multicolumn{5}{|c|}{ Panel B: Regression Results } \\
\hline \multirow{5}{*}{$\begin{array}{c}\text { Education } \\
\text { laws }\end{array}$} & Dependent Variable: Education & & & & \\
\hline & Childlaw $=$ Work age-enter age & $0.036^{* *}$ & $0.092 * *$ & $0.039^{* *}$ & 0.044 \\
\hline & & $(.014)$ & $(.022)$ & $(.019)$ & $(.026)$ \\
\hline & Continuation School Required $(=1)$ & $0.153^{* *}$ & $0.190^{*}$ & -0.085 & -0.023 \\
\hline & & $(.057)$ & $(.105)$ & $(.053)$ & $(.111)$ \\
\hline
\end{tabular}

Standard errors (in parenthesis) are robust. All coefficients derived from regressions that use the same controls as in Table 3. Sample includes all individuals.

** significant at $5 \%,{ }^{*}$ significant at $10 \%$. 
TABLE 10: Endogeneity Test

\begin{tabular}{|c|c|c|c|}
\hline Dependent Variable & Average Education & & \\
\hline & & Expla & y Variable \\
\hline Lead & Statistics & Childlaw & Future Childlaw \\
\hline 3 years & $\beta$ & .019 & -.020 \\
\hline & s.e. & $(.020)$ & $(.021)$ \\
\hline & $\mathrm{N}$ & 316 & 316 \\
\hline 4 years & $\beta$ & $.036 * *$ & -.008 \\
\hline & s.e. & $(.018)$ & $(.027)$ \\
\hline & $\mathrm{N}$ & 352 & 352 \\
\hline 5 years & $\beta$ & $.033 * *$ & .036 \\
\hline & s.e. & $(.016)$ & $(.023)$ \\
\hline & $\mathrm{N}$ & 384 & 384 \\
\hline 6 years & $\beta$ & $.044 * *$ & .018 \\
\hline & s.e. & $(.017)$ & $(.020)$ \\
\hline & $\mathrm{N}$ & 414 & 414 \\
\hline 7 years & $\beta$ & $.047 * *$ & .013 \\
\hline & s.e. & (.017) & $(.019)$ \\
\hline & $\mathrm{N}$ & 419 & 419 \\
\hline 8 years & $\beta$ & $.055^{* *}$ & $.035^{*}$ \\
\hline & s.e. & $(.016)$ & $(.020)$ \\
\hline & $\mathrm{N}$ & 417 & 417 \\
\hline 9 years & $\beta$ & $.053 * *$ & -.010 \\
\hline & s.e. & $(.017)$ & $(.032)$ \\
\hline & $\mathrm{N}$ & 403 & 403 \\
\hline 10 years & $\beta$ & $.053 * *$ & $.058 * *$ \\
\hline & s.e. & $(.018)$ & $(.025)$ \\
\hline & $\mathrm{N}$ & 360 & 360 \\
\hline 11 years & $\beta$ & $.046^{* *}$ & -.012 \\
\hline & s.e. & $(.012)$ & $(.031)$ \\
\hline & $\mathrm{N}$ & 315 & 315 \\
\hline 12 years & $\beta$ & $.037 *$ & -.049 \\
\hline & s.e. & $(.019)$ & $(.034)$ \\
\hline & $\mathrm{N}$ & 274 & 274 \\
\hline
\end{tabular}

All $\beta$ come from different regressions. The regressions include the same variables as in Table 3 . The standard errors (in parenthesis) are robust.

** significant at the 5\% level, * significant at the $10 \%$ level 


\section{Appendix A: Sources of Data for Compulsory Attendance Laws and Child Labor Laws}

\begin{tabular}{|c|c|c|}
\hline Year & Compulsory Attendance Laws & Child Labor Laws \\
\hline 1915 & $\begin{array}{l}\text { US Department of Labor, Children's Bureau, } \\
\text { Child Labor Legislation in the United States, } \\
\text { Publication No. } 10 \text { by Sumner, Helen L. and Ella } \\
\text { A. Merrit, Washington: US GPO } 1915 \\
\text { Reviewed with: } \\
\text {-US Office of Education. State Law on } \\
\text { Compulsory Attendance Circular No. } 793 \text { by } \\
\text { August W. Steinhilber and Carl J. Sokolowsky, } \\
\text { US GPO } 1966\end{array}$ & $\begin{array}{l}\text {-US Department of Labor, Children's Bureau, } \\
\text { Child Labor Legislation in the United States, } \\
\text { Publication No. } 10 \text { by Sumner, Helen L. and Ella } \\
\text { A. Merrit, Washington: US GPO } 1915\end{array}$ \\
\hline 1918 & $\begin{array}{l}\text { Department of the Interior. Bureau of Education, } \\
\text { Biennial Survey of Education 1916-1918, } \\
\text { Bulletin No. 90, } 191 \text { Washington: US GPO } 1921 \\
\text { Reviewed with: } \\
\text {-U.S. Department of Health, Education, and } \\
\text { Welfare. Compulsory School Attendance and } \\
\text { Minimum Educational Requirements in the } \\
\text { United States, Circular } 440 \text { by W. W. Keesecker. } \\
\text { Washington: US GPO } 1955\end{array}$ & $\begin{array}{l}\text { Department of the Interior. Bureau of Education, } \\
\text { Biennial Survey of Education 1916-1918, Bulletin } \\
\text { No. 90, } 191 \text { Washington: US GPO 1921 }\end{array}$ \\
\hline 1921 & $\begin{array}{l}\text { U.S Department of Labor, Children's Bureau. } \\
\text { State Compulsory Attendance Standards } \\
\text { Affecting the Employment of Minors. Chart No. } 2 \\
\text { Washington: US GPO } 1921\end{array}$ & $\begin{array}{l}\text { U.S Department of Labor, Children's Bureau and } \\
\text { Federal Board for Vocational Education. Child } \\
\text { Care and Child Welfare. Federal Board for } \\
\text { Vocational Education, Home Economics Series } \\
\text { No.5. Bulletin No.65, Washington GPO } 1921\end{array}$ \\
\hline 1924 & $\begin{array}{l}\text { U.S Department of Labor, Children's Bureau. } \\
\text { State Compulsory Attendance Standards } \\
\text { Affecting the Employment of Minors. Chart No. } 2 \\
\text { Washington: US GPO } 1924\end{array}$ & $\begin{array}{l}\text { U.S Department of Labor, Children's Bureau. } \\
\text { State Child-Labor Standards. Chart No. } 1 \\
\text { Washington: US GPO } 1924\end{array}$ \\
\hline 1928 & $\begin{array}{l}\text { US Department of the Interior, Bureau of } \\
\text { Education. Laws Relating to Compulsory } \\
\text { Education. Bulletin No. } 20 \text { by Ward W. } \\
\text { Keesecker, US GPO } 1929\end{array}$ & $\begin{array}{l}\text { US Department of the Interior, Bureau of } \\
\text { Education. Laws Relating to Compulsory } \\
\text { Education. Bulletin No. } 20 \text { by Ward W. } \\
\text { Keesecker, US GPO } 1929\end{array}$ \\
\hline 1929 & $\begin{array}{l}\text { US Department of Labor, Children's Bureau. } \\
\text { Child Labor: Facts and Figures. Bulletin No. } \\
\text { 197. Washington: US GPO, } 1930\end{array}$ & $\begin{array}{l}\text { US Department of Labor, Children's Bureau. } \\
\text { Child Labor: Facts and Figures. Bulletin No. } 197 . \\
\text { Washington: US GPO, } 1930\end{array}$ \\
\hline 1930 & $\begin{array}{l}\text { U.S Department of Labor, Children's Bureau. } \\
\text { State Compulsory Attendance Standards } \\
\text { Affecting the Employment of Minors. Chart No. } 2 \\
\text { Washington: US GPO } 1930\end{array}$ & $\begin{array}{l}\text { U.S Department of Labor, Children's Bureau. } \\
\text { State Child-Labor Standards. Chart No. } 1 \\
\text { Washington: US GPO } 1930\end{array}$ \\
\hline 1935 & $\begin{array}{l}\text { US Department of the Interior, Office of } \\
\text { Education. Compulsory School Attendance Laws } \\
\text { and Their Administration. Bulletin No. } 4 \text { by W } \\
\text { W Keesecker and W S Deffebaugh, US GPO } \\
1935\end{array}$ & $\begin{array}{l}\text { US Department of the Interior, Office of } \\
\text { Education. Compulsory School Attendance Laws } \\
\text { and Their Administration. Bulletin No. } 4 \text { by W W } \\
\text { Keesecker and W S Deffebaugh, US GPO } 1935\end{array}$ \\
\hline
\end{tabular}




\begin{tabular}{lll}
\multicolumn{2}{l}{ Appendix A continued } & \\
\hline Year & Compulsory Schooling Laws & Child Labor Laws \\
\hline 1939 & - US Office of Education, Pupil Personnel \\
& $\begin{array}{l}\text { Education, Bulletin No.6, 1940, Monograph 5 } \\
\text { (1918-1939) }\end{array}$ \\
& -U.S. Department of Health, Education, and \\
& Welfare. Compulsory School Attendance and \\
& $\begin{array}{l}\text { Minimum Educational Requirements in the } \\
\text { United States, Circular 440 by W. W. Keesecker. } \\
\end{array}$ \\
Washington: US GPO 1955
\end{tabular}

Further Notes: Information about following variables was not available in the cited publications:

-1918: continuation school laws.

-1929: Entrance age

-1939: Education to dropout, Education to work and Continuation school

Years in between were imputed using the previous laws. However, for certain years, I used additional information to correct certain variables:

1916: corrected Entrance age, Leaving age, Education to dropout and Work permit age using U.S Department of Labor, Children's Bureau. Summary of Child-Welfare Laws passed in 1916. Bureau Publication No. 21. US GPO 1917.

1923: corrected Entrance age, Leaving age and Education to dropout, using US Office of Education, Bulletin No.2, US GPO 1925

1925: corrected Leaving age and Continuation school using U.S Department of Labor, Children's Bureau. Important Legislative Changes Made in 1925 in Child Labor Standards and In Compulsory School Attendance Standards Affecting the Employment of Minors.

1926 and 1927: corrected Education to work using U.S Department of Labor, Children's Bureau. Child Labor and Compulsory School Attendance Measures passed by the state Legislatures meeting in 1926 and 1927.

1936: corrected Work permit age using U.S Department of Labor, Children's Bureau. Child Labor. US GPO 1936

1937: corrected Work permit age, Entrance age, Leaving age and Education to dropout using U.S Department of Labor, Children's Bureau. Child Welfare Legislation, 1937, Bureau Publication No. 236, US GPO 1938

1939: corrected Work permit age using: Merrit, Ella A., "Trend of Child Labor, 1937 to 1939”, Monthly Labor Review. January 1940

\section{Definitions of various compulsory education and child labor variables}

Entrance age: maximum at which a child must enter school

Leaving age: minimum age at which a child can leave school

Education to dropout: years of schooling needed to be exempted from school according to compulsory attendance laws

Work permit age: Minimum Age at which can obtain a work permit

Education to work: years of schooling needed to obtain a work permit

Continuation school $=1$ if state required children that were exempted from school or that had a work permit to attend continuation, evening or part time school. Compulsory evening school was included, unless it was required only of illiterate individuals.

Continuation school age: Age until which child had to attend continuation school

Comlaw = leaving age-entrance age: implied years of compulsory schooling according to compulsory attendance laws.

Childlaw $=$ work permit age-entrance age: implied years of compulsory schooling according to child labor laws 


\section{Appendix B: State Level Data}

-Data on education expenditures and number of schools buildings per state comes from several years of the Biennial Survey of Education. The data was exits for even years, starting in 1916. Fortunately earlier data for 1914 also exits and was published in the Statistical Abstract of the United States. Data for years in between was imputed using a linear interpolation.

-Data about the percentage of population employed in manufacturing and wages in the manufacturing sector comes from the Census of Manufactures. It was collected every two year and is available for all odd years. Data for years in between was imputed using linear interpolation.

-Data on the percentage of the population that lived in urban areas, percentage of black population and percentage white foreign born come from the census and it is only available every ten years. Data for years in between was imputed using a linear interpolation by state.

-Data on average value of farm property per farm and per acre of farm land was reported in the Statistical Abstract of the United States for 1910, 1920, 1925, 1930 and 1940. Data for years in between was generated using a linear interpolation by state.

-Data about states' population comes from the Statistical Abstract of the United States. Accurate measures are only available every ten years from the Census, but estimates for every year where published as well. These estimates are used to calculate all the per capita measures, when per capita measures where not already available.

-Data on infant mortality rates comes form the National Vital Statistics. The state time series going form 1915 to 1950 were published in1950. Data for early years was not available for all states. Missing values were imputed using a linear trend by state.

-Data on number of hospitals and physicians comes from several years of the American Medical Directory published every year since 1906 by the American Medical Association. Data is available at the state level for the following years: 1906, 1909, 1912, 1914, 1916, 1918, 1921, 1923, 1925, 1927, 1929, 1931, 1934, 1936, 1938, 1940 (and beyond). Missing values were imputed using linear interpolation.

-All monetary values (education expenditures, manufacturing wages, net income and farm value) were converted into real dollars using the Consumer Price Index series provided by the Bureau of Labor Statistics online at ftp://ftp.bls.gov/pub/special.requests/cpi/cpiai.txt. 1982-84 is the base period.

-Measurement units: Population: in thousands; number employed in manufacturing: actual number; wages in manufacturing: in thousands; net income: in thousands; number of school buildings: actual number; expenditures in education: in thousands; number of farms: actual number; value of farm property: in thousands; all land in farms: in thousands. 


\section{Apendix C: Summary Statistics. Individual Level Data}

\begin{tabular}{|c|c|c|c|c|c|c|}
\hline Variable & & Obs & Mean & Std. Dev. & Min & Max \\
\hline Dependent & Years of completed education & 478591 & 10.16 & 3.44 & 0 & 18 \\
\hline \multirow{8}{*}{$\begin{array}{l}\text { Education } \\
\text { Laws }\end{array}$} & Age at which can leave school & 475366 & 15.81 & 1.03 & 12.00 & 20 \\
\hline & Age at which must enter school & 475366 & 7.35 & 0.56 & 6.00 & 9 \\
\hline & Comlaw $=$ leave-enter & 478591 & 8.39 & 1.47 & 0 & 12 \\
\hline & Childlaw $=$ Work age-enter age & 478591 & 6.81 & 1.25 & 0 & 10 \\
\hline & Education required to dropout & 478591 & 6.63 & 3.35 & 0 & 12 \\
\hline & Minimum Age for Work Permit & 477420 & 14.22 & 0.88 & 7.00 & 18 \\
\hline & Education required for Work Permit & 478591 & 4.94 & 3.05 & 0 & 8 \\
\hline & Continuation School Required $(=1)$ & 478591 & 0.62 & 0.48 & 0 & 1 \\
\hline \multirow{4}{*}{$\begin{array}{c}\text { Individual } \\
\text { characteristics }\end{array}$} & female & 478591 & 0.51 & 0.50 & 0 & 1 \\
\hline & black & 478591 & 0.10 & 0.29 & 0 & 1 \\
\hline & Other race & 478591 & 0.00 & 0.06 & 0 & 1 \\
\hline & Parents foreign born & 478591 & 0.16 & 0.37 & 0 & 1 \\
\hline \multirow{9}{*}{$\begin{array}{c}\text { State } \\
\text { Characteristics }\end{array}$} & $\%$ urban & 478591 & 51.49 & 21.70 & 12.30 & 97.50 \\
\hline & $\%$ foreign & 478591 & 10.98 & 8.64 & 0.40 & 31.30 \\
\hline & $\%$ black & 478591 & 10.95 & 13.64 & 0.01 & 54.20 \\
\hline & $\%$ employed in manufacturing & 478591 & 0.06 & 0.04 & 0.00 & 0.28 \\
\hline & Annual Manufacturing wage & 478591 & 6986.18 & 1465.96 & 713.03 & 12095.16 \\
\hline & Value of farm per acre & 478591 & 521.88 & 275.75 & 47.70 & 1802.58 \\
\hline & Per capita number of doctors & 478591 & 0.00 & 0.00 & 0.00 & 0.00 \\
\hline & $\begin{array}{l}\text { Per capita expenditures on } \\
\text { education }\end{array}$ & 478591 & 92.29 & 42.83 & 5.37 & 601.39 \\
\hline & \# of school buildings per sq. mile & 478591 & 0.17 & 0.09 & 0.00 & 0.47 \\
\hline
\end{tabular}

Sample: All people born in the 48 states between 1901 and 1925 whose educational attainment is not missing from the 1960 Census. 